\title{
Dynamic Model of Islamic Hybrid Securities: Empirical Evidence From Malaysia Islamic Capital Market
}

\author{
Jaafar Pyeman (Corresponding Author) \\ Faculty of Business \& Management \\ Universiti Teknologi MARA, 42300, Bandar Puncak Alam, \\ Selangor Darul Ehsan, Malaysia \\ Tel:- +6016-220 6114 E-mail: jaaf@salam.uitm.edu.my \\ Mohamad Nizam Jaafar \\ Faculty of Business \& Management \\ Universiti Teknologi MARA, 42300, Bandar Puncak Alam, \\ Selangor Darul Ehsan, Malaysia \\ Tel:- +603-3258 7045 E-mail: mnizam7520@salam.uitm.edu.my \\ Ismail Ahmad \\ Faculty of Business \& Management \\ Universiti Teknologi MARA, 42300, Bandar Puncak Alam, \\ Selangor Darul Ehsan, Malaysia \\ Tel:- +603-32587045 E-mail: drismailahmad@salam.uitm.edu.my
}

\begin{abstract}
Capital structure selection is fundamentally important in corporate financial management as it influence on mutually return and risk to stakeholders. Despite of Malaysia's position as one of the major players of Islamic Financial Market, there are still lack of studies has been conducted on the capital structure of shariah compliant firms especially related to hybrid securities. The objective of this study is to determine the hybrid securities issuance model among the shariah compliant firms in Malaysia. As such, this study is to expand the literature review by providing comprehensive analysis on the hybrid capital structure and to develop dynamic Islamic hybrid securities model for shariah compliant firms. We use panel data of 50 companies that have been issuing the hybrid securities from the year of 2004- 2012. The outcomes of the studies are based on the dynamic model GMM estimation for the determinants of hybrid securities. Based on our model, risk and growth are considered as the most determinant factors for issuing convertible bond and loan stock. These results suggest that,
\end{abstract}

the firms that have high risk but having good growth prospect will choose hybrid securities of convertible bond. The model also support the backdoor equity listing hypothesis by Stein (1992) where the hybrid securities enable the profitable firms to venture into positive NPV project by issuing convertible bond as it offer lower coupon rate as compare to the normal debt rate

Keywords : Capital structure; Islamic hybrid securities; Panel data, GMM

\section{Introduction}

The requirement for raising capital is escalating in conjunction with the growth of the firms' business. The two most common ways of raising external capital is either by issuing equity or via incurring debt respectively. Obtaining capital via shares or equity from the public is carry out in the stock market. Meanwhile securing debt is normally by either borrowing from the financial institutions or by issuing debt securities such as commercial papers, bonds and notes and in the capital market. In addition to debt and equity, 
there are another option of rising capital namely via hybrid security which has gradually become one of the important securities issuance choice. Hybrids securities also generally are deeply within the issuer's capital structure. Typically, hybrid securities are ranking lower to other forms of debt but higher to common stock. As a result, the rating agency and regulator always give good rating to the issuers when they analyzing the issuers' capital structure position.

The literature offers several hypothesis that motivated the issuance of hybrid issuance namely risk shifting exercise (Green 1984), backdoor equity financing (Stein 1992) and sequential financing problem (Mayers 1998) The reason for Green (1984) to proposed risk shifting hypothesis is to address the issue of minimizing agency cost arise from the conflict of interest between bondholder and shareholders. Stein (1992) through it backdoor equity hypothesis proposed on how the firms using hybrid as the substitute for common equity as indirect financing in order to minimize the cost related to direct equity offering. Meanwhile, Mayer (1998) extend Stein's model(1992) of "backdoor equity hypothesis" by including sequential financing problems. Mayer(1998) claim that issuing hybrid securities offer lower financing cost as hybrid financing carry lower coupon rates than straight debts (due to the conversion option features) and has the possibility to sell off at a premium prices.

This study's objective is to develop model of hybrid Securities issuance within the Malaysia Islamic capital market. Despite Islamic finance does not have any element of interest in its activities, the shariah complaint firms still require capital in the form of both debt, equity and also hybrid securities. To-date, most of the studies of capital structure are only focus their study on developed countries' such as the USA (Titman and Wessels, 1988; Shyam-Sunder and Myers, 1999; Fama and French, 2002) and the UK (Marsh, 1982; Bevan and Danbolt, 2002) and very limited study conducted based on the newly emerged capital market namely
Islamic capital market. A remarkable enquiry that arises on this study is what motivates the shariah compliant firms to issue hybrid security. Does shariah compliant firms have the similar motivation as what being inspired by conventional firms specifically based on theories of hybrid securities such as shifting exercise (Green 1984), backdoor equity financing (Stein 1992) and sequential financing problem (Mayers 1998). The paper is organized as follows. Section 2 is briefly summarizing the theory capital structure particularly on the hybrid capital structure. Section 3 discusses the data and empirical method used in this study, Section 4 presents the empirical results of the analysis and Section 5 concludes the paper.

\section{Literature Reviews}

The foundation of the modern theory of capital structure was initiated from Modigliani-Miller (M\&M) theorem, established by Franco Modigliani and Merton Miller (1958). This theory stated that a firm's capital structure choice does not affect the firm's value when the capital market is prefect or efficient with the assumption of there is no taxes imposed, no issuing cost for raising capital via debt or equity and no agency cost respectively. Nevertheless, it is contradict to the real world practice which eventually attribute to several other theories were also found to challenge this studies and define the optimal capital structure for the firms in a various perspective such as agency theory, (Jensen and Meckling, 1976, Smith and Warner 1979, Pinegar and Wilbricht 1989, Lubatkin and Chatterjee 1994, Elliot 2002), asymmetric information, (Akerlof, 1970; Myers and Majluf, 1984; Clarke and Shastri, 2001; Hasbrouck, 2005), pecking order theory (Myers and Majluf, 1984; Mayers, 2001; Fama and French, 1998), bankruptcy cost (Berger et al, 1995; Florackis, 2008), risk shifting (Green, 1984; Lewis et al., 1999), backdoor equity financing (Stein, 1992; Lewis et al., 1999).

The popular argument among practitioners for the reasons of choosing for hybrid securities 
instead of debt i.e. convertible bond is because of the cost factor. Convertible bond carry lower coupon rate as compared to the normal bond and subsequently permit the issuers to sell the security at a premium over the current prices where the conversion price is higher that the stock price (Mayers, 2000). This is in line with Mayer's model of Sequential Financial problem (Mayers 1998) which is extension from the "backdoor equity hypothesis model" (Stein, 1992).

Stein (1992) proposed that backdoor equity financing theory that the firms are able to delay issuance of equity via hybrid financing when they face high degree of informational asymmetries cost making less attractive to issue equity. As such, convertible debt stand for a financing option that diminished the unpleasant selection costs of an immediate sale of equity. This facilitates the firms to issue equity without having to acquire higher financial risk. Thus, Lewis et al. (1999) argue that although convertible debt issuers may have firm characteristics that are similar to equity issuers, leveraged firms that are optimistic about their future investment opportunities but that are subject to significant information asymmetries, are more likely to choose convertible debt or straight debt. However, Stein (1992) notes should the firm that having significant asymmetric information proceed with the issuance of straight debt may attribute to firms to face other value decrease costs. When the financial distress is very expensive, firms that are highly gearing and have poor future cash flow will relinquish straight debt issues. Consequently, financial distress costs prevail over unfavourable selection costs. Stein (1992) concludes that convertible bonds are a replacement for equity and that this substitute is most probable to take place in firms facing major information asymmetries and high financial distress costs.

\section{Empirical Methodology and Measurement of The Variables.}

The sample consists of 50 listed firms that are shariah compliant listed on Bursa Malaysia and Ace Market over the years 2004 - 2012. We choose to apply panel data considering it enables to conduct the study on more complicated behavioural models as the panel data provides larger data points, more variability, and therefore increases the degree of freedom and minimizes the collinear among variables. We use GMM for our model as GMM is capable to resolve the problems of hetroscedasticity and autocorrelation respectively.

The companies selected are consisting of the one that issue hybrid securities namely convertibles bond and loan stock during the period under review. Generally, there are various types of hybrid instruments in Malaysia capital market namely bond with convertible loan, bond with warrant, structured warrant, company warrant, loan stock and others. Nevertheless, due to limited issuance by the firms, we only include convertible bond and loan stock for our model of study. Besides, we are also assuming that all hybrid issuance securities by shariah compliant firms as the Islamic hybrid securities. This is because not all shariah compliant firms are issuing Islamic hybrid securities per se and there are also under some circumstances that non shariah firms are issuing Islamic hybrid products. Hopefully, in the future, all these shariah compliant firms will only issue Islamic hybrid securities for capital requirement.

\section{Emprical Model}

To develop the hybrid capital structure model in the Malaysia Islamic capital market, the hybrid leverage ratios of individual firms are modeled as a function of several firm specific factors in a cross sectional framework. As such, this study will incorporate all the attributes that were described in the next section. The general estimation model is as follows:- 


\section{Regression based on OLS}

$\mathrm{LEV}$ it $=\alpha+\beta \mathrm{i} 1 \mathrm{SIZE}$ it $+\beta \mathrm{i} 2 \mathrm{AG}$ it $+\beta \mathrm{i} 3$ TS it $+\beta \mathrm{i} 4$ NTS it $+\beta \mathrm{i} 5$ PROFit + $\beta$ i6TAit $+\beta$ i7GRit $+\beta$ i8FR $+\beta$ i9FF U it

where LEV it is measured by total hybrid capital namely convertible bond and loan stock divided by the firm's shareholders fund. The basic regression method applied in this model will be the Ordinary Least Squares (OLS).

From the descriptive analysis in item 4.0, it shows that the majority of the data under review are not distributed in a normal manner. Therefore the model is not suitable for OLS regression technique and instead the GMM regression is considered to more suitable as it is more efficient to cater on the non-normal distributed data and could address on the issue of hetroscedasticity and autocorrelation respectively.

The following is the explanation on the theoretical relationship between independent variable and the variables that suggested in the literature as determinants of hybrid securities issuance. GMM is explained based on OLS matrices.

Referring to the basic assumption of OLS, error term $\overline{\mathrm{u}}=0$.

Therefore, from the regression $y=b_{x}+u$, we can get the coefficient, $b=\left(X^{\prime} X^{\prime}\right)^{-1} X^{\prime} y^{51,} n$ the form of matrices, and $\hat{y}=X\left(X^{\prime} X\right)^{-1} X^{\prime} y=P x y$ because $\mathrm{y}=\mathrm{bx}+\mathrm{u}$, where $\mathrm{P}_{\mathrm{x}}$ is a projection matrix. Based on the assumptions of the instruments, $\operatorname{cov}(\mathrm{z}, \mathrm{x}) \neq 0$ and $\operatorname{cov}(\mathrm{z}, \varepsilon)=0$, the IV estimator can be written as the following:

$\mathrm{E}\left\{\mathrm{u}_{\mathrm{i}}, \mathrm{z}_{\mathrm{i}}\right\}=\mathrm{E}\left\{\left(\mathrm{y}_{\mathrm{i}}-\mathrm{x}^{\prime}{ }_{\mathrm{i}} \mathrm{b}\right) \mathrm{z}_{\mathrm{i}}\right\}=0$ where $\mathrm{z}$ is $\mathrm{T} \mathrm{x} \mathrm{k}$ instruments which satisfy the moment condition, $\mathrm{E}\left(\mathrm{Z}_{\mathrm{i}}^{\prime} \mathrm{u}_{\mathrm{i}}\right)=0$; and $\mathrm{b}_{\mathrm{iv}}=\left(\mathrm{Z}^{\prime} \mathrm{X}\right)^{-1} \mathrm{Z}^{\prime} \mathrm{y}$ if endogenous variables are just identified.

When it is over identification, then the instrument matrix is not symmetric and is not possible to calculate. To resolve this, we require minimizing quadric form with weighting matrix $\mathrm{W}_{\mathrm{N}}$

$\mathrm{Q}_{\mathrm{N}}(\mathrm{b})=\left[\mathrm{N}^{-1} \mathrm{Z}^{\prime}(\mathrm{y}-\mathrm{Xb})\right]^{\prime} \mathrm{W}_{\mathrm{N}}\left[\mathrm{N}^{-1} \mathrm{Z}^{\prime}(\mathrm{y}-\mathrm{Xb})\right]$

This entailed $X^{\prime} Z W_{N} Z^{\prime} y=X^{\prime} Z W_{N} Z^{\prime} X b_{i v}$, and $b_{\text {iv }}\left(X^{\prime} Z W_{N} Z^{\prime} X\right)^{-1} X^{\prime} Z W_{N} Z^{\prime} y$

as $W_{N}$ pursue the method of moment with minimising the quadric loss function, the optimal weighting matrix is

$N$

$N^{-1} \sum z_{i} z_{i}$

$i=1$

The IV is a special case of GMM. When an equation is just identified, IV and GMM turn up at the same result. Unlike the IV estimator, GMM does not require i.i.d of error term. Just like IV, coefficients of GMM is decided by:

$$
\boldsymbol{B}_{G M M}=\left(X^{\prime} Z W_{N Z} Z^{\prime} X\right)^{-1} X^{\prime} Z W_{N} Z^{\prime} y .
$$

The estimator of GMM on $\mathrm{W}_{\mathrm{N}}, \mathrm{W}_{\mathrm{N}}=\left(\mathrm{N}^{-1} \sum\right.$ $\left.\hat{U}^{2} Z_{i} Z^{\prime}\right)^{-1}=\left(Z^{\prime}{ }^{\prime}{ }^{\prime} Z^{-153}\right.$ where weighing matrix $\mathrm{W}_{\mathrm{N}}$ is a covariance matrix. Thus, the GMM allows heteroskedasticity of $u_{i}$ (Davidson and Mackinnon,2004; Baum, 2006; Verbeek, 2008). Therefore, the GMM estimator becomes;$$
b_{G M M}=\left(X^{\prime} Z\left(Z^{\prime} u{ }^{\prime} Z\right)^{-1} X^{\prime} Z\left(Z^{\prime} u u Z\right)^{-}\right.
$$ ${ }^{1} \boldsymbol{Z}^{\prime} \boldsymbol{y}$}

Therefore, the study includes a lagged dependent variable and new error term on the right hand of the equation 1 .

\section{Model 1}

LEV it $=\alpha\left({ }_{\mathrm{I}, \mathrm{t}-1)}+e_{1}\right.$ SIZE it $+\mathrm{e}_{2} \mathrm{AG}$ it + $e_{3}$ TS it $+e_{4}$ NTSit $+e_{5}$ PROF it + бi6 TA it $+6 i 7 \mathrm{GR}$ it $+6 \mathrm{i} 8 \mathrm{FR}+6 \mathrm{igFF}$ it + 6i10SM it $+\sigma i_{11}$ BMit $+\sigma i_{12}$ ECON it $+\sigma i_{13}$ INT it + 
Uit + E it

(6)

\section{Company size (SIZE)}

Natural logarithm of total assets (Warner, 1977; Titman \& Wessel, 1988; Rajan \& Zingales, 1995; Gaud et al, 2005; Kim C.S, 2010). The issuing of capital is based on the size of the company. The established firm is more preferable to issue debt in line with trade off theory, Tinman \& Wessel (1988). It recommended that the larger company has the lesser possibility of default which feature to better entrance to credit market. Besides that, large firms have a tendency to be more diversified and have low bankruptcy risk in contrast to the smaller firms. The positive correlation between company size and debt issuance is further supported by the studies conducted by Myers (1982), Friend and Lang (1988), Chiarella et al (1992), Lasfer (1995) Another studies conducted by Kim, Mauer and Sherman (1998) and Hovakimian et al (2004) also shows that large firms issued debt while the small firms has high tendency to issue equity

\section{Age (AG)}

Various capital structure studies considered age of the firm as one of the important determinant of capital structure, Bhaduri (2002), Andres et al. (2005), Crabbe and Post (1994.

\section{Tax Consideration}

\section{Debt Tax Shield (TS)}

The ratio of tax paid over total asset( Suchard and Singh, 2006). According to tradeoff theory (Modigliani \& Miller, 1963), the firms that record high tax shield are more likely to take advantage of interest deduction from tax by issuing debt. By opting to debt financing, the features of interest that allow tax deductibility would raise the firm's after tax cash flow. There are several evidence shown that tax benefits are among the reasons for the firm's in selecting its financing option.(Graham, 1996, Titman and Wessel, 1998)

\section{Non-debt tax shield (NTS)}

The ratio of depreciation to total asset- Titman and Wessels (1988), Ozkan(2001).As suggested by the tradeoff theory (Modigliani \& Miller, 1963), firms can use non debt tax shield such as depreciation to save corporate tax. Therefore, a higher non debt tax shield such as depreciation and investment tax credit deduction, lower the possibility tax benefit of debt and the firms opt issuance of other than debt i.e. equity, convertible debt.

\section{Profitability (PROF)}

Earning before interest and Tax divided by total assets. (Rajan \& Zingales, 1995; Gaud et al, 2005). The calculation of earning before interest and Tax divided by total assets for ratio of profitability is widely used by many studies. The firms optimal financing and success in assets utilizations are reflected in the firms' profitability as stated by Myers (1977) in pecking order theory, Myers and Majluf (1984) and Booth et al. (2001).

\section{Asset Tangibility (TA)}

The ratio of total fixed asset to total asset. (Chen 2004; Guad et all; 2005). This proxy is related to the tradeoff theory (Modigliani \& Miller, 1963). The firms that recorded higher asset tangibility reflecting that the firms are having more collateral. As such, they have more tendencies to raise capital via issuing debt with lower cost of interest in conjunction with firm's low risk of bankruptcy. On the other hand, the firms that with low collateral will have to opt for either equity or warrant. From prospective of agency cost theory, Jensen and Meckling (1976) and Myers (1977) point out, shareholders of levered firms may have the motivation to invest in high risk business in contrast to the firm's bondholders which only opt for lower risk business. However, If 
the debt can be collateralized, the borrower is reserved or limited to utilize the funds for a particular project, reducing the agency costs of asset substitution and hence, the costs of debt. As a result, the trade-off theory predicts a positive association between the tangibility of assets and leverage.

\section{Growth Opportunity (GR)}

Annual growth rate in sales (Titman \& Wessel, 1998; Chen,2004; Kim C.S, 2010). There are various measure have been adopted by various studies. Rajan and Zingales (1995) is using market to book ratio as the proxy for growth. Nevertheless, according to Titman and Wessel (1998) and further supported by Chen et al (2005), the growth of revenue reflect better proxy for the growth opportunity. The growth opportunities is found by Chen and Zhao (2004) as one of the security issuance choice determinants where their study shows a stronger reliance of firms with higher growth opportunities on debt financing rather than equity financing. This also supported by (Ghosh, et al, 2000; Anderson and Makhija, 1999; Prowse ,1990; Rajan and Zingales, 1995; Smith and Watts, 1992; Stulz, 1990; Titman and Wessels, 1988; Kim and Sorensen, 1986.

\section{Financial Flexibility (FF)}

Cash and Marketable Securities over current assets ( Singh and Hodder, 2000). This variable is only being recently applied in the study of the determinant of corporate capital structure. In general, the current literature has given only one description on financial flexibility namely the ratio of cash and marketable securities over current assets. ( Singh and Hodder, 2000, Upneja and Dalbor, 2000 and Chen and Jiang, 2001).

\section{Financial Risk (FR)}

Long term debt to total asset (Suchard and Singh ,2006). According to Suchard and Singh (2006), the firms that have high financial risk will be more likely to issue equity or from the prospective of hybrid instrument will be warrant. This is in line with pecking order model, financial distress cost and sequential financing model hypothesis respectively. This is in conjunction with the result found in Jung et al (1996) that examine the selection between straight debt and equity.

\section{Descriptive Analysis}

Table 1 -Descriptive Statistics

\begin{tabular}{|c|c|c|c|c|c|c|}
\hline Variables & Mean & Median & Std Dev & Skewness & Kurtosis & Jerque Bera \\
\hline \multirow{2}{*}{ Lev } & \multirow[b]{2}{*}{0.0921} & \multirow[b]{2}{*}{0.068} & \multirow[b]{2}{*}{0.099} & \multirow[b]{2}{*}{4.987} & \multirow[b]{2}{*}{41.24} & 19070.19 \\
\hline & & & & & & 0.0000 \\
\hline \multirow[t]{2}{*}{ AGE } & \multirow[t]{2}{*}{27.95} & \multirow[t]{2}{*}{25.00} & \multirow[t]{2}{*}{17.45} & \multirow[t]{2}{*}{0.9688} & \multirow[t]{2}{*}{4.22} & 64.21 \\
\hline & & & & & & 0.0000 \\
\hline \multirow[t]{2}{*}{ SIZE } & \multirow[t]{2}{*}{6.07} & \multirow[t]{2}{*}{6.01} & \multirow[t]{2}{*}{0.069} & \multirow[t]{2}{*}{0.6229} & \multirow[t]{2}{*}{3.82} & 27.28 \\
\hline & & & & & & 0.0000 \\
\hline \multirow{2}{*}{ TS } & \multirow[b]{2}{*}{0.0082} & \multirow[b]{2}{*}{0.0079} & \multirow[t]{2}{*}{0.008} & \multirow[t]{2}{*}{-0.1213} & \multirow[t]{2}{*}{15.28} & 27.28 \\
\hline & & & & & & 0.0000 \\
\hline \multirow[t]{2}{*}{ NTS } & \multirow[t]{2}{*}{0.0169} & \multirow[t]{2}{*}{0.0133} & \multirow[t]{2}{*}{0.013} & \multirow[t]{2}{*}{3.8768} & \multirow[t]{2}{*}{22.69} & 5468,7 \\
\hline & & & & & & 0.0000 \\
\hline PROF & 0.0739 & 0.07 & 0.068 & -1.478 & 24.62 & 5815 \\
\hline
\end{tabular}




\begin{tabular}{|c|c|c|c|c|c|c|}
\hline & & & & & & 0.0000 \\
\hline TA & 0.448 & 0.419 & 0.13 & 1.5 & 6.735 & $\begin{array}{l}279.87 \\
0.0000\end{array}$ \\
\hline GR & 0.1806 & 0.17 & 1.635 & 14.33 & 142.69 & $\begin{array}{r}215803 \\
0.0000\end{array}$ \\
\hline FR & 0.3838 & 0.375 & 0.175 & -0.11 & 2.47 & $\begin{array}{c}4.17 \\
0.0000\end{array}$ \\
\hline FF & 0.1248 & 0.114 & 0.1101 & 1.67 & 14.039 & $\begin{array}{l}1637.56 \\
0.0000\end{array}$ \\
\hline SM & 138.9868 & 144.66 & 26.4733 & -0.925 & 3.15 & $\begin{array}{c}39.43 \\
0.0000\end{array}$ \\
\hline BM & 84.207 & 85 & 8.417 & 0.022 & 1.39 & $\begin{array}{c}27.89 \\
0.0000\end{array}$ \\
\hline GDP & 4.871 & 5.58 & 2.659 & -1.725 & 4.607 & $\begin{array}{l}156.43 \\
0.0000\end{array}$ \\
\hline BFR & 6.283 & 6.27 & 0.3739 & -0.644 & 2.536 & $\begin{array}{c}20.21 \\
0.0000\end{array}$ \\
\hline
\end{tabular}

In addition to the mean - median comparison

Stock Market, Bond Market and Interest rate and standard deviation, the data is also tested using numerous methods such as the skewness test, kurtosis, the Jarque Bera respectively. This is to discover the data under review are normally distributed or otherwise.

Table 1, reflect that the data under review are not normally distributed. Exception to LEV, SIZE, TANG, and FR the values of mean and median, as shown in column one and two, are not the equal. Only SIZE, Tangibility, FR, have the skewness of the variables, equal to approximately zero. Finally, the values of Jarque-Bera, as indicated in the table, apart from being significant, it rejects the hypothesis that the data are normally distributed. These preliminary findings reveal that the estimation model using OLS could not generate better model. Instead, GMM is more suitable and expected to produce better estimation model as GMM manage to address the issue of heterocedasticity in the data under review.

\section{Emprical Result and Discussion}

Table 2 - Regression Result

System GMM on Model 1

\begin{tabular}{lccccc}
\hline leverage & Coef. & Std Error & $\mathbf{Z}$ & $\mathbf{P}>[\mathbf{z}]$ & [95\% conf. Interval] \\
\hline leverage & & & & & \\
L1 & 0.0492 & 0.0263 & 1.87 & 0.042 & -0.01770 \\
Age & 0.0612 & 0.0319 & 1.92 & 0.047 & 0.0152 \\
Size & 0.8321 & 0.3438 & 2.42 & 0.014 & 0.0551 \\
Tax shield & 0.6903 & 0.1717 & 4.02 & 0.000 & 0.3115 \\
Non tax shield & -0.1143 & 0.0386 & -2.96 & 0.003 & -2.1541 \\
Profitability & 0.9112 & 0.4821 & 1.89 & 0.041 & -0.2313 \\
Tangibility & 0.7174 & 0.2104 & 3.41 & 0.000 & 0.0512 \\
Growth & 0.0731 & 0.0234 & 3.13 & 0.001 & -2.0134 \\
Financial Risk & 0.0313 & 0.0080 & 3.92 & 0.000 & -2.0121 \\
Financial Flexibility & 0.2231 & 0.0538 & 4.15 & 0.000 & 0.123 \\
SM & -0.0034 & 0.0016 & -2.13 & 0.033 & 2.123 \\
& & & & 0.002 & 2.124 \\
\end{tabular}


GJAT | DECEMBER 2016 | VOL 6 ISSUE 2 | 14

ISSN : 2232-0474 | E-ISSN : 2232-0482

www.gjat.my

\begin{tabular}{|c|c|c|c|c|c|c|}
\hline $\mathrm{BM}$ & 0.0056 & 0.0030 & 1.89 & 0.049 & 0.00011 & 0.00061 \\
\hline GDP growth & 0.0321 & 0.0226 & 1.42 & 0.042 & 0.00413 & 0.54321 \\
\hline cons & 2.323 & 0.7328 & 3.17 & 0.031 & 0.0213 & 6.123 \\
\hline No of instruments & 40 & & & & & \\
\hline No of observations & 173 & & & & & \\
\hline Wald chi2(12) & 18.33 & & & & & \\
\hline Prob $>$ chi 2 & 0.1061 & & & & & \\
\hline \multicolumn{7}{|c|}{$\begin{array}{l}\text { Arrelano Bond test for } A R(1) \text { in first differences : } z=-1.72 \mathrm{pr}>z=0.086 \\
\text { Arrelano Bond test for } A R(2) \text { in first differences : } z=-0.75 p r>z=0.454\end{array}$} \\
\hline
\end{tabular}

The model shows a positive correlation between leverage $\mathrm{CB}$ and age, size, tax shield, profitability, FR, growth, tangibility, BM, and GDP growth. Nevertheless, it has a negative relationship with non tax shield and SM.

Meanwhile, the risk and profitability are considered the most determinant factors for issuing convertible bond and loan stock. These results suggest that, the firms that expose with high risk but strong financial position will choose convertible bond. This can be related to the scenario in Malaysia where the authorities emphasize on conservative credit policies. Malaysian financial institutions generally offer debt to strong financial position firms that hold low risk of financial distress or bankruptcy. Since the high risk firms but profitable are difficult to secure additional credit facility from the financial institutions, there always opt for hybrid security of convertible bond as proposed by risk shifting theory where hybrid securities allow the high risk firm to further venture into riskier business.

Age is very much related to asymmetric information. Many studies find out that information asymmetries are likely to be large for young firms as they are relatively unknown institution and the cost of outside finance includes a premium to cover the risk implied by this uncertainty. In line with Rajan and Zingales (1995), the firms under review demonstrate that the established firms raise more hybrid capital to ease their capital requirement. For size, the established firm is more preferable to issue debt ( convertible bond) in line with trade off theory, Tinman \& Wessel (1988). It suggested that the larger company has the lower risk of default which attribute to better access to credit market. Besides that, large firms tend to be more diversified and have low bankruptcy risk as compare to the smaller firms. Meanwhile, the tax shield positively correlated with convertible bond leverage is in line with literature of capital structure. The literatures in general are recommending a positive connection between tax and debt issuance in line with the benefits of tax by leveraging (Modigliani and Miller, 1963). The main factor to choose debt for financing is to take advantage of interest tax shields or tax deductible of interest. Meanwhile with regard to tangibility, the firms that recorded higher asset tangibility reflecting that the firms are having more collateral. As such, they have more tendencies to raise capital via issuing debt (Convertible bond) with lower cost of interest in conjunction with firm's low risk of bankruptcy.

The hybrid debt securities namely the convertible debt are also the answer to the firm that face high degree of informational asymmetries cost making less attractive to issue equity. As such, convertible debt stand for a financing option that diminished the unpleasant selection costs of an immediate sale of equity. This facilitates the firms to issue equity without having to acquire higher financial risk as being proposed in the backdoor equity listing hypothesis by Stein (1992).

The firms with a high risk position but having high growth position are more likely to employ convertible debt as they can finance the interest payments and firms, with lower cost. High risk firm normally difficult to secure debt facility and if it could it will be at very high cost rate. 
By issuing convertible bond, the firm could secure financing at lower rate and eventually convert the debt into equity and premium price, Based on the result in table 2, risk and growth are positively correlated with hybrid leverage. This is outcome is in line with backdoor equity listing hypothesis by Stein (1992) .

In addition, the study shows a positive relationship between bond markets, interest rate, GDP with leverage convertible bond respectively. The positive signed in the bond market development with leverage indicate that the bond market development is growing in tandem with leverage issuance. Meanwhile, the rise in interest rate will attract more investors to invest in the interest based products which include convertible bond. As the economy growth as indicated by the positive GDP, the demand for the firm to raise capital will also increase which attribute to the positive correlation between convertible bond leverage and GDP.

\section{Conclusion}

This research has established a dynamic model that is significant in determining hybrid securities for debt feature hybrid signifies by convertible bond and loan stocks. From the model, risk and growth is considered one of the most determinant factor for issuing convertible bond and loan stock. These results suggest that, the firms that have high risk but having good growth prospect will choose hybrid securities of convertible bond. This can be related to the scenario in Malaysia where the authorities emphasize on conservative credit policies. Malaysian financial institutions generally offer debt to strong financial position firms that hold low risk of financial distress or bankruptcy. Since the high risk firms difficult to secure additional credit facility from the financial institutions, there always opt for hybrid security of convertible bond. The result from the model also support the backdoor equity listing hypothesis by Stein (1992) where the hybrid securities enable the profitable firms to venture into positive NPV project by issuing convertible bond as it offer lower coupon rate as compare to the normal debt rate. Subsequently, the convertible bond could also converted into equity with premium price.

\section{References}

Anderson, C.W. \& Makhija, A.K. 1999. Deregulation, disintermediation and agency costs of debt: evidence from Japan. Journal of Financial Economics, 51(2), 309-339.

Bhaduri, S. (2002). Determinants of corporate borrowing : Some evidence from the Indian corporate structure. Journal of Economics and Finance, 26(2), 200-215.

Beaver, W., Eger, C., Ryan, S., \& Wolfson, M. (1989). Financial reporting, supplemental disclosures, and bank share prices. Journal of Accounting Research, 27(2), 157-178.

Fama, F. \& French, R. (1998). Taxes, Financing Decisions, and Firm Value. Journal of Finance, 53(3), 819.

Florackis, C. (2008). Agency costs and corporate governance mechanisms: evidence for UK firms. International Journal of Managerial Finance, 4(1), 37-59.

Friend, I. and Hasbrouk, J. (1988) Determinants of Capital Structure, Research in Finance, 7, $1-19$.

Ghosh, A., Cai, F. \& Li, W. 2000. The determinants of capital structure. American Business Review, 18(2), 128-132.

Green, R., (1984). Investment Incentives, Debt, and Warrants. Journal of Financial Economics, $13,115-136$.

Hovakimian, A Opler, T \& Titman, S. (2001). The debt equity choice. Journal of financial quantitative Analysis, 36, 1-24. 
Hovakimian, A. and I. Hutton (2010). Market feedback and equity issuance: Evidence from repeat equity issues. Journal of Financial and Quantitative Analysis, 45(3), 739-762.

Jensen, M. C. and Meckling, W. H. (1976). Theory of the Firm: Managerial Behavior, Agency Costs and Ownership Structure. Journal of Financial Economics, 3,305-360.

Jensen, M. C. (1986). Agency Costs of Free Cash Flow, Corporate Finance and Takeovers, American Economic Review, 76,323-329.

Jensen, M., Geralg, P. and Thomas, S. (1992). Simultaneous Determination of Insider Ownership, Debt, and Dividend policies. Journal of financial and Quantitative Analysis, 27, 247-263.

Kim, C.S., Mauer, D.C. and Sherman, A.E (1998). The determinant of corporate liquidity: Theory and evidence. Journal of financial and qualitative analysis, 33, 335-358.

Kim, C. S. and Eric H. S. (1986). Evidence on the Impact of Agency Costs of Debts in Corporate debt Policy. Journal of Financial Economics, 22:189-205.

Marsh, P. (1982). The Choice between Equity and Debt: An Empirical Study. Journal of Finance, 37(1), 121-144.

Modigliani, F. (1958). The cost of capital, corporate finance and the theory of investment. The American Economic Review, 3, 261-297.

Modigliani, F. and Miller, M. (1963). Corporate Income Taxes and the Cost of Capital, A correction. American Economic Review, 53, 433-44.

Myers, S. C. (1998). Why firms issue Convertible bonds : The matching financial and real investment options. Journal of Financial Economics, 47, 83-102.
Myers, S. C. (2000). Convertible bonds : Matching financial and real option. Journal of Applied Corporate Finance, 13(1), 8-21.

Myers, S. C. (2001). Capital Structure. Journal of Economic Perspectives, 15(2), 81- 102.

Myers, S. C. and Majluf, N. S. (1984). Corporate Financing and Investment Decisions When Firms have Information That Investors Do Not Have. Journal of Financial Economics, 13,187221.

Rajan, R. G. and Zingales, L. (1995) What Do We Know about Capital Structure? Some Evidence from International Data, Journal of Finance, 5,1421-1460.

Shyam-Sunder, L. \& Myers, S. C. (1999). Testing static tradeoff against pecking order models of capital structure. Journal of Financial Economics, 51(2), 219-244.

Smith, C. and Warner, J. (1979). On Financial Contracting: An Analysis of Bond Covenants. Journal of Financial Economics, 117-162.

Smith, C. and Watts, R. (1992). 'The Investment Opportunity Set and Corporate financing, Dividend, and Compensation Policy'. Journal of Financial Economics, 32, 263-292.

Stein, J. C. (1992). Convertible debt as backdoor equity financing. Journal of Financial Economics, 32, 3-21.

Stulz, R. (1990). Managerial Discretion and Optimal Financing Policies. Journal of Financial Economics, 26, 3-27.

Suchard, J. A. and Singh, M. (1996). The determinants of the hybrid securities issuance decision for Australian firms. Pacific Basin Finance Journal, 14, 269-290. 
Titman, S. and Wessels, R. (1988). The Determinants of Capital Structure Choice. Journal of Finance, 43(1), 1-19.

Warner, J. (1977). Bankruptcy Costs: Some Evidence. Journal of Finance, 32, 337-347. 